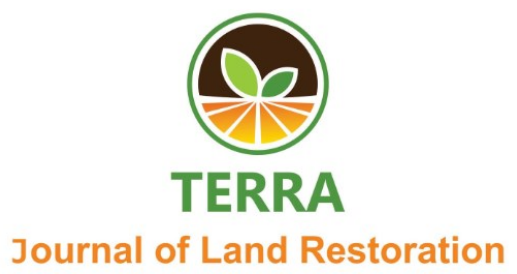

\title{
Stem Cutting Growth of Red Dragon Fruit (Hylocereus costaricensis) due to Aplication of Cow Manure and $\mathrm{KCl}$ in Andosol
}

\author{
Irfan Nofriandi $^{1}$, Faiz Barchia $^{2 *}$, Fahrurrozi $^{1}$, Bilman W. Simanihuruk ${ }^{1}$, Entang Inoriah Sukarjo ${ }^{1}$ \\ ${ }^{1}$ Agroecotechnology Department, University of Bengkulu \\ ${ }^{2}$ Soil Science Department, University of Bengkulu (Corresponding author)
}

e-mail: faizbarchia@gmail.com

\begin{abstract}
This study aims to obtain the optimum dose of manure for red dragon fruit plant growth on Andosol, optimum K fertilizer dose for red dragon fruit plant growth on Andosol, and the interaction of manure and $K$ fertilizer for red dragon fruit plant growth on Andosol. This research was conducted from August 2018 to November 2018 at the Horticulture Seed Center, Kepahiang Regency, Bengkulu Province. This study used a completely randomized design (CRD) consisting of two factors with three replications. The first factor is cow manure, which is $0 \mathrm{~g} / \mathrm{polybag,} 20 \mathrm{~g} / \mathrm{polybag}, 40 \mathrm{~g} /$ polybag, and $60 \mathrm{~g} /$ polybag. The second factor is Kfertilizer, which is $0 \mathrm{~g} /$ polybag, $1.38 \mathrm{~g} / \mathrm{polybag}, 2.76 \mathrm{~g} / \mathrm{polybag}$, and $5.52 \mathrm{~g} /$ polybag. The results showed that the application of cow manure with a dose of $60 \mathrm{~g} / \mathrm{polybag}$ resulted in the best shoot growth time and shoot fresh weight.
\end{abstract}

Keywords: cow manure, $\mathrm{KCl}$ fertilizer, andosol, red dragon fruit

\section{INTRODUCTION}

Dragon fruit (Hylocereus sp) is a new plant known by the Indonesian people but is quite popular because of its sweet taste and various health benefits. According to the history of its spread, dragon fruit plants were first discovered in Mexico and South America. Indians have long used Dragon fruit, but so far, it has never been reported in the world mass media because of the lack of information (Winarsih, 2007). Dragon fruit is a cactus plant of various types, including white flesh, red flesh, and yellow flesh. Red-fleshed dragon fruit is the fruit that people like the most compared to other types of dragon fruit because of its sweet taste and attractive flesh color (Satria, 2011). Bioactive substances contained in dragon fruit are beneficial for the body, including antioxidants (in ascorbic acid, beta-carotene, and anthocyanins) and contain dietary fiber in the form of pectin. In addition, dragon fruit contains several minerals such as calcium, phosphorus, iron, and others. The vitamins contained in dragon fruit include vitamin $\mathrm{B} 1$, vitamin $\mathrm{B} 2$, vitamin $\mathrm{B} 3$, and vitamin $\mathrm{C}$ (Pratomo, 2008).
The need for dragon fruit in Indonesia reaches 200-400 tons per year, but the availability of dragon fruit is still less than $50 \%$ of the market per year (Winarsih, 2007). Therefore, developing seeds and planting dragon fruit has become a business field in Indonesia (Samadi, 2013). Dragon fruit plant seeds can be produced through generative and vegetative means. The productive method is minimal because it takes a long time for the seeds to be ready for planting in the field, while vegetative propagation is often done on dragon fruit plants (Nurfadilah et al., 2012). One of the advantages of dragon fruit propagation through cuttings is that the seeds produced are uniform, propagation is faster and the same as the parent (Kristanto, 2009). While the drawback of cuttings propagation is that the growth substances are not evenly distributed, so growth is not uniform (Hartman \& Kester, 1983).

The need for dragon fruit seeds is $4400-5800$ seeds/ha depending on the spacing (Samadi, 2013). Currently, the development and cultivation of dragon fruit in Indonesia are still concentrated in several areas such as Java, Sumatra, and Kalimantan. Kristanto (2009) stated that the development and cultivation of 
dragon fruit on the island of Java are in East Java, including Pasuruan, Jember, Mojokerto, and Jombang. As a result, dragon fruit plants are not widely known by the wider community. Cultivation of dragon fruit plants requires high organic matter and nutrients; one type of soil with high organic matter and nutrients for dragon fruit cultivation is the soil of the order Andosol.

Andosols are young soils formed from volcanic materials, characterized by two unique properties, namely black color due to high organic matter content and andic properties due to amorphous mineral content. Andosol soil contains a relatively high level of nutrients derived from the ash of volcanic eruptions. The physical fertility of Andosol soil is also supported by its increased ability to bind water and porosity and drainage properties that are favorable for plant development (Balai Penelitian dan Pengembangan Pertanian, 2014). One aspect of good plant growth is to do proper fertilization. Organic fertilizer is a complete fertilizer because it contains macro and microelements, even in small amounts (Prihmantoro, 1996). In addition to the nutrients $\mathrm{N}$, $\mathrm{P}, \mathrm{K}, \mathrm{S}$, and other microelements, the advantages of organic fertilizers are improving soil structure, increasing soil absorption of water, improving living conditions in the soil because microorganisms in the soil play a critical role in overhauling organic matter, as a source of nutrients $\mathrm{N}, \mathrm{P}, \mathrm{K}, \mathrm{S}$, and other microelements (Prihmantoro, 2005).

Fertilization of dragon fruit plants can be done by providing manure and $\mathrm{KCl}$. Organic fertilizers are fertilizers derived from the remains of plants, animals, and industrial residues (Lingga, 1986). One of the organic fertilizers that can improve soil structure is cow manure. Cow manure contains macronutrients, namely $0.3 \% \mathrm{~N}, 0.2 \% \mathrm{P}_{2} 0_{5}, 0.15 \% \mathrm{~K}_{2} \mathrm{O}$, and $0.2 \% \mathrm{CaO}$ content. According to the results of Asari's research (2016), the application of cow manure with the treatment of $35 \mathrm{~g} /$ polybag sizes $25 \mathrm{~cm} \times 30$ $\mathrm{cm}$ resulted in the best growth of super red dragon fruit stem cuttings, namely shoots appeared at the age of 18 , and 25 days after planting (dap), shoot length at the age of 18 and 25 dap. Seventy-five days after planting, $49.48 \mathrm{~cm}$. The provision of potassium fertilizer helps root development, helps the process of protein and carbohydrate formation, increases plant resistance to disease and drought. Solpiati (2013) stated that another function of potassium is to help the formation of proteins and carbohydrates. Potassium also plays a role in strengthening the plant body so that flowers and fruit do not fall easily. Plants deficient in potassium are characterized by shriveled leaves and red-brown spots that dry and then die (Marsono \& Sigit, 2001).

The results of Tri et al. (2000) showed that the need for one year $\mathrm{K}_{2} \mathrm{O}$ for mature dragon fruit plants is $300 \mathrm{~g} /$ tree. The growth of dragon fruit plants with treatments of $100 \mathrm{~g}$ and $200 \mathrm{~g}$ of NPK Mutiara with $16 \% \mathrm{~N}$ content, $16 \% \mathrm{P}_{2} \mathrm{O}_{5}$, and $16 \% \mathrm{~K}_{2} \mathrm{O}$ resulted in varied plant height growth (Irwanto, 2015). The treatment that showed the highest plant growth compared to other treatments was giving 200 grams of NPK/plant with a $\mathrm{K}$ content of $32 \mathrm{~g} /$ plant.

This study aims to obtain the optimum dose of cow manure for dragon fruit plant growth, obtain the optimum dose of $\mathrm{KCl}$ fertilizer for dragon fruit plant growth, and obtain the interaction of cow manure and $\mathrm{KCl}$ fertilizer for dragon fruit plant growth in Andosol.

\section{MATERIALS AND METHODS}

This research was conducted from August to November 2018 at the Horticultural Seed Center of Kepahiang Regency, Bengkulu Province. The materials used in this study were stem cuttings of red dragon fruit taken from the Hortiutura Seed Center, Kepahiang Regency, polybags measuring $30 \mathrm{~cm} \mathrm{x}$ $35 \mathrm{~cm}$ and $23 \mathrm{~cm}$ in diameter, planting media namely soil, cow manure, and $\mathrm{KCl}$ fertilizer, and the tools used in this study.

This study used a completely randomized design (CRD) consisting of two factors. The first factor is dose of cow manure, namely $0 \mathrm{~g}$ /polybag, 20 $\mathrm{g} /$ polybag, $40 \mathrm{~g} /$ polybag, and $60 \mathrm{~g} /$ polybag. The second factor was dose of $\mathrm{KCl}$ fertilizer, which was $0 \mathrm{~g} /$ polybag, $1.38 \mathrm{~g} / \mathrm{polybag}, 2.76 \mathrm{~g} / \mathrm{polybag}$, and $5.52 \mathrm{~g} /$ polybag. Each treatment was repeated three times so that there were 48 experimental units. Variabel yang diamati berupa variabel tanah, iklim, dan tanaman.

Data collected from plant variables is analyzed statistically with analysis of variance (ANOVA) at an absolute level of 5\%. If diversity analysis shows a fundamental difference, proceed with the Orthogonal Polynomial to obtain a relationship between the independent and dependent variables.

\section{RESULT AND DISCUSSION}

This study was conducted from August to November 2018 at Balai Benih Hortikulture located in Pematang Donok Village, Kabawetan Subdistrict, Kepahiang Regency, 600- $800 \mathrm{~m}$ above sea level with Andosol soil type. The results of the initial soil analysis of the study showed that the research land had a soil pH of 5.2, which is classified as sour, Corganic by $7.19 \%$, which is relatively high, and $\mathrm{K}$ dd of $0.24 \mathrm{me} / 100 \mathrm{~g}$ of soil that is relatively low. In general, the soil analysis results show that the land used is andosol soil that has the fertility rate of the soil by what is needed by red dragon fruit.

Data on rainfall, air temperature, air humidity, and length of solar irradiation during the study were obtained from the BMKG station of Bengkulu 
province. During the study (August-November), Rainfall was $64 \mathrm{~mm}, 67 \mathrm{~mm}, 212 \mathrm{~mm}$, and $513 \mathrm{~mm}$. Dragon fruit plants initially get relatively low rainfall, but rainfall has increased drastically in the last two months. However, dragon fruit can still grow in high rainfall of about 1,000-1,300 mm / year (Emil, 2011). During the study, the air temperature ranged from $21.9{ }^{\circ} \mathrm{C}-$ $25.8 \mathrm{oC}$, air humidity ranged from $81 \%-97 \%$, and the length of solar irradiation ranged from 0 hours 9 hours.

During the implementation of the study, the treatments carried out include watering and weed control that is considered disturbing. Weeds that grow around plants are broad-leafed, narrow-leafed weeds that are not identified. During the growth of cuttings, no diseases attack dragon fruit plants.

The results of the variance analysis showed that the application of cow manure with different doses had a noticeable effect on the time of growth of shoots and the fresh weight of shoots, but had no noticeable effect on the length of shoots, the number of shoots, and the dry weight of the shoots. The application of $\mathrm{KCl}$ fertilizer doses had no significant effect on all observed plant variables. Likewise, the interaction of cow manure and $\mathrm{KCl}$ fertilizer has a non-significant impact on all observed plant variables (Table 1).

Table 1. Summary of the results of the variance of Stem Cutting Growth of Red Dragon Fruit (Hylocereus costaricensis) due to Aplication of Cow Manure and $\mathrm{KCl}$ in Andosol

\begin{tabular}{|c|c|c|c|c|}
\hline \multirow[b]{2}{*}{ Variable } & \multicolumn{3}{|c|}{ F value } & \multirow[b]{2}{*}{ CV $(\%)$} \\
\hline & $\begin{array}{c}\text { Cow ma- } \\
\text { nure }\end{array}$ & $\mathrm{KCl}$ & $\begin{array}{l}\text { Interac- } \\
\text { tion }\end{array}$ & \\
\hline Length of shoots & $1.49 \mathrm{~ns}$ & $0.3 \mathrm{~ns}$ & $1.21 \mathrm{~ns}$ & 18.48 \\
\hline Number of shoots & $2.11 \mathrm{~ns}$ & $2.4 \mathrm{~ns}$ & $2.76 \mathrm{~ns}$ & 13.65 \\
\hline $\begin{array}{l}\text { Time of growth } \\
\text { shoots }\end{array}$ & $3.63^{*}$ & $2.59 \mathrm{~ns}$ & $2.01 \mathrm{~ns}$ & 9.5 \\
\hline $\begin{array}{l}\text { Fresh weight of } \\
\text { shoots }\end{array}$ & $4.81^{*}$ & $1.2 \mathrm{~ns}$ & $1.28 \mathrm{~ns}$ & 24.78 \\
\hline $\begin{array}{l}\text { Dry weight of } \\
\text { shoots }\end{array}$ & $2.54 \mathrm{~ns}$ & $1.82 \mathrm{~ns}$ & $1.03 \mathrm{~ns}$ & 22.61 \\
\hline
\end{tabular}

(*) Significantly different ; (ns) Non Significantly different

Effect of Cow Manure Dosage on the Growth of Red dragon fruit Stem Cuttings

The relationship between manure and growth time of red dragon fruit stem cuttings forms a linear relationship with the line equation $\mathrm{y}=6.8167$ -
$0.0258 \mathrm{x}$ with a value of $\mathrm{R}^{2}=0.7657$ (Figure 1 ). The model shows the role of the dose of cow manure on the time of growth shoots by an average of $76.57 \%$.

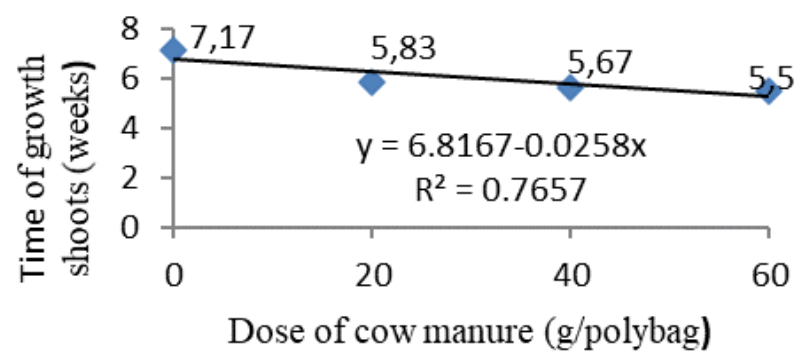

Figure 1. Relationship between cow manure and time of growth shoots

The dose of cow manure $60 \mathrm{~g} /$ polybag resulted in the fastest shoot growth time of 5.5 weeks. The results of Asari \& Marisi's research (2016) showed that stem cuttings that received a dose of cow manure produced shoots faster than those without cow manure. Dragon fruit plants without fertilizer application experienced poor growth. This is due to the lack of nutrients needed by plants. The use of manure can complement nutrient deficiencies, both macro, and microelements, in the soil so that plant growth becomes better (Solpiati, 2013; Hasibuan, 2015).

The results showed that cow manure had a significant effect on fresh shoot weight (Table 1). The relationship between organic fertilizer and fresh weight of shoots red dragon fruit is presented in (Figure 2). An increase will follow the addition of 1 $\mathrm{g} /$ polybag cow manure in fresh weight of shoots by an average of $0.9207 \mathrm{~g}$. The model of the relationship between these two variables explained the role of cow manure on the fresh weight of shoots by an average of $96 \%$.

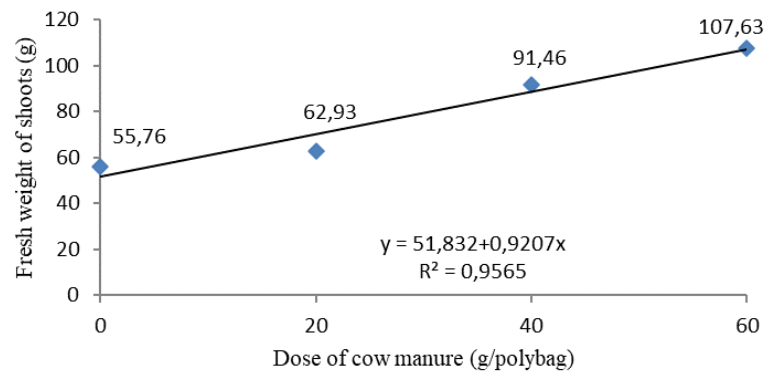

Figure 1. Relationship between cow manure and fresh weight of shoots growth shoots

The application of cow manure $60 \mathrm{~g} /$ polybag had the best effect on adding a fresh shoot weight of $107.63 \mathrm{~g}$. According to Moenandir (1993), fresh plant weight is 
influenced by water and nutrient absorption by plants. The absorption of water and nutrients by plants depends on the reserves of water and nutrients absorbed and the ability to absorb them. Manure helps increase the availability of water and nutrients in plants, including shoots, so that shoots have high water content and increase the fresh weight of the shoots (Wahyono et al., 2015). The application of kendang fertilizer causes the availability of water and nutrients to be higher when compared to without the application of manure so that the fresh weight is higher.

The analysis of variance showed that the dose of cow manure had no significant effect on shoot length, number of shoots, and shoot dry weight (Table 1). However, it can be seen that the higher the cow manure dose is given, the most extended length of shoots, the highest number of shoots, and the heaviest dry weight of shoots (Table 2).

Table 2. Average results of cow manure research on the growth of red dragon fruit stem cuttings

\begin{tabular}{cccc}
\hline $\begin{array}{c}\text { Dose of cow } \\
\text { manure } \\
(\mathrm{g} / \text { polybag})\end{array}$ & $\begin{array}{c}\text { Length of } \\
\text { shoots } \\
(\mathrm{cm})\end{array}$ & $\begin{array}{c}\text { Number of } \\
\text { shoots } \\
(\text { shoot })\end{array}$ & $\begin{array}{c}\text { Dry weight of } \\
\text { shoots } \\
(\mathrm{g})\end{array}$ \\
\hline 0 & 16.71 & 1.42 & 3.95 \\
20 & 17.28 & 1.67 & 4.74 \\
40 & 21.34 & 1.67 & 5.48 \\
60 & 21.72 & 2.17 & 7.22 \\
\hline
\end{tabular}

The dose of cow manure of $60 \mathrm{~g} /$ polybag on dragon fruit cuttings resulted in an average shoot length of $21.72 \mathrm{~cm}$, number of shoots 2.17 , and shoot dry weight of $7.22 \mathrm{~g}$. This result was more significant than that produced by dragon fruit cuttings that obtained cow manure doses of 0 to $40 \mathrm{~g} /$ polybag (Table 2). However, the actual dose range of 20 to $60 \mathrm{~g} /$ polybag of manure has stimulated the growth process of dragon fruit shoots.

This is different from the research of Asari (2016) and Nurfadilah et al. (2012) because when the study used PGR, which contains hormones that promote growth and cell division. The more cell division occurs, the more shoots are formed and develop in red dragon fruit plants. However, it did not spur the emergence of new shoots quickly. While this study did not use growth-promoting hormones, cell division and growth were inhibited; thus, shoot length and number of shots were not formed optimally even though the dose of fertilizer treatment could accelerate the emergence of shoots.

The dry weight of shoots results from plant photosynthesis; when carrying out the research, the plants have not been able to translocate the photosynthetic results to all plant organs properly. This resulted in the dry weight of the shoots being uniform in each given treatment. Febriansyah's research (2018) on cucumber plants also shows the same phenomenon. The results of plant photosynthesis influence the dry weight mass in cucumber plants during the vegetative and generative periods. The greater the photosynthesis produced, the heavier the dry weight mass-produced.

\section{The Effect of KCl Fertilizer Application on the Growth of Red Dragon Fruit Stem Cutting}

The results of the analysis of variance showed that the application of $\mathrm{KCl}$ fertilizer had no significant effect on shoot length, shoot number, shoot growth time, shoot fresh weight and shoot dry weight (Table 1). The average variable growth of red dragon fruit stem cuttings is shown in Table 3.

Table 3. Average research results of $\mathrm{KCl}$ fertilizer application on the growth of red dragon fruit stem cutting

\begin{tabular}{cccccc}
\hline $\mathrm{KCl}$ & \multicolumn{5}{c}{ Variables } \\
\cline { 2 - 6 } $\begin{array}{c}\text { (g/ } \\
\text { polybag) }\end{array}$ & $\begin{array}{c}\text { Length } \\
\text { of }\end{array}$ & $\begin{array}{c}\text { Number } \\
\text { of }\end{array}$ & $\begin{array}{c}\text { Time of } \\
\text { growth } \\
\text { shoots } \\
(\text { (cm) }\end{array}$ & $\begin{array}{c}\text { Fresh } \\
\text { weight } \\
\text { of } \\
\text { shoots } \\
(\mathrm{g})\end{array}$ & $\begin{array}{c}\text { Dry } \\
\text { weight } \\
\text { of } \\
\text { shoots } \\
(\mathrm{g})\end{array}$ \\
\hline 0 & 19.68 & 1.33 & 6.33 & 74.95 & 4.19 \\
1,38 & 20.64 & 1.92 & 6 & 87.64 & 6.88 \\
2,76 & 17.83 & 1.58 & 6.67 & 64.4 & 4.69 \\
5,52 & 18.9 & 2.08 & 5.17 & 90.82 & 5.63 \\
\hline
\end{tabular}

A dose of $1.38 \mathrm{~g}$ of $\mathrm{KCl}$ fertilizer produced the most extended shoot length of $20.64 \mathrm{~cm}$, while the shortest $17.83 \mathrm{~cm}$ was produced by a dose of $2.76 \mathrm{~g}$ of $\mathrm{KCl}$ fertilizer. The application of $\mathrm{KCl}$ fertilizer as $5.52 \mathrm{~g}$ resulted in the highest average number of shoots being 2.08 shoots, while the minor data was seen in the control of 1.33 shoots. The application of $2.76 \mathrm{~g} \mathrm{KCl}$ fertilizer resulted in the highest shoot growth time variable average of 6.67 weeks, while the most minor data was seen in the application of $5.52 \mathrm{~g} \mathrm{KCl}$ fertilizer of 5.17 weeks. In applying 5.52 $\mathrm{g} \mathrm{KCl}$ fertilizer, the highest average fresh shoot weight variable was $90.82 \mathrm{~g}$. In comparison, the smallest data was seen in the application of $2.76 \mathrm{~g}$ $\mathrm{KCl}$ fertilizer of $64.4 \mathrm{~g}$. The application of $1.38 \mathrm{~g}$ $\mathrm{KCl}$ fertilizer resulted in the highest shoot dry weight variable average of $6.88 \mathrm{~g}$, while the most minor data on the control was $4.19 \mathrm{~g}$.

The application of $\mathrm{KCl}$ fertilizer had no statistically significant effect because plants could not adequately absorb the $\mathrm{K}$ element contained in $\mathrm{KCl}$ fertilizer. Nutrient K more dominantly affects plants 
in the generative phase when compared to the vegetative phase. Plants require large amounts of $\mathrm{K}$. This is in line with Subandi's research (2013) which shows that the critical role of element $\mathrm{K}$ is to determine the yield of plant production compared to plant growth. The results of previous research conducted by Kushendarto \& Pangaribuan (2009) showed that the dose of $\mathrm{KCl}$ fertilizer $0-40 \mathrm{~g} /$ plant did not significantly affect plant growth.

\section{CONCLUSION}

Cow manure dose increased shoot growth time and shoot fresh weight linearly, but had no significant effect on shoot length, shoot number, and shoot dry weight. The dose of $\mathrm{KCl}$ fertilizer given had no significant effect on each of the observed variables. The significant interaction between cow manure and $\mathrm{KCl}$ dose was not significant for all growth variables of red dragon fruit cuttings..

\section{References}

Asari \& Napitupulu, M. (2016). Pengaruh pemberian pupuk kandang sapi dan ZPT hantu terhadap pertumbuhan stek batang tanaman buah naga daging Super Merah (Hylocereus costaricencis). Journal Agriculture and Forestry, 15 (2), 179-186. DOI: 10.31293/af.v15i2.2074.

Febriansyah. (2018). Efektivitas Aplikasi Beberapa Konsentrasi Pupuk Organik Cair Berbasis Daun Lamtoro Terhadap Pertumbuhan dan Hasil Tanaman Mentimun (Cucumis sativus L). Skripsi. Universitas Bengkulu, Bengkulu.

Hartman \& Kester. (1983). Plant Propagation Principle and Practise. Prentice Hall. Internasional Inc. Engelwoods Clifs., New Jersy.

Hasanah, F. N. \& Setiari, N. (2007). Pembentukan akar pada stek batang nilam (Pogostemon $\mathrm{Ca}$ blin Benth.) setelah direndam IBA (Indol Butyric Acid) pada konsentrasi berbeda. Buletin Anatomi dan Fisiologi. 15(2), 1-6. DOI: https:// doi.org/10.14710/baf.v15i2.2566.

Hasibuan, A.S.Z. (2015). Pemanfaatan bahan organik dalam perbaikan beberapa sifat tanah pasir Pantai Selatan Kulon Progo. Planta Tropika Journal of Agro Science,3(1),31-40. DOI: https:// doi.org/10.18196/pt.2015.037.31-40.

Irwanto. (2015). Pengaruh Pemberian Pupuk NPK Terhadap Pertumbuhan Tanaman Buah Naga di Kecamatan Pemayung, Kabupaten Batanghari, Propinsi Jambi. Widyaiswara Balai Pelatihan Pertanian Jambi, Jambi.

Kesuma, K.A.G., Ete, A., Noer, A. (2017). Pengaruh Berbagai Jenis Pupuk Organik pada Panjang Stek yang Berbeda terhadap Pertumbuhan
Bibit Buah Naga ( Hylocereus costaricensis). e-Journal Agrotekbis, 5(1), 27 - 35.

Kristanto, D. 2009. Buah Naga Pembudidayaan di Pot dan di Kebun. Penerbit Penebar Swadaya, Jakarta.

Kushendarto., D.H. pangaribuan. 2009. Pengaruh Pemupukan Fosfor dan Kalium terhadap Pertumbuhan dan Produksi Buah Naga. Prosiding Seminar Hasil Penelitian \& Pengabdian Kepada Masyarakat, Universitas Lampung, Bandar Lampung.

Lingga, P. (1986). Petunjuk Penggunaan Pupuk Organik. Penebar Swadaya, Jakarta.

Maharani, E, Rabaniyah, R. \& Yudono, P. (2012). Pengaruh Lapisan Debu Gunung Merapi dan Dosis Pupuk NPK Terhadap Pertumbuhan Awal Buah Naga (Hylocereus undatus Haw.) di Lahan Pasir Pantai Purwerejo. Skripsi. Universitas Gajah Mada, Yogyakarta.

Marsono., Sigit, P. (2001). Pupuk Akar Jenis dan Aplikasi. Penebar Swadaya, Jakarta.

Moenandir, J. (1993). Ilmu Gulma Dalam Sistem Pertanian. Raja Grafindo Persada, Jakarta.

Nurfadilah, Armaiini, Yeti, H. (2012). Pertumbuhan bibit buah naga (Hylocereus costaricensis) dengan perbedaan panjang stek dan konsentrasi Zat Pengatur Tumbuh. JOM Fakultas Pertanian, Universitas Riau, 1(1), 1-12.

Pratomo. (2008). Superioritas Jambu Biji dan Buah Naga. Agromedia Pustaka, Jakarta.

Prihmantoro, H. (1996). Memupuk Tanaman Buah. Cetakan I. Penebar Swadaya, Jakarta.

Prihmantoro, H. (2005). Memupuk Tanaman Sayuran. Penebar Swadaya, Jakarta.

Samadi, B. (2013). Untung Berlipat dari Buah Naga Secara Organik. Lily Publisher. Andi Offset

Satria, F. (2011). Pengaruh Beberapa Konsentrasi Atonik Pada Pertumbuhan Stek Buah Naga Berdaging Merah (Hylocereus costaricensis (Web) Britton \& Ross). Skripsi. Universitas Andalas, Padang.

Solpiati. (2013). Pengaruh Pemberian Pupuk Organik Cair Nasa Terhadap Pertumbuhan Tanaman Buah Naga Super Red (Hylocereus costaricensis). Skripsi. Program Studi Budidaya Tanaman Perkebunan Jurusan Manajemen Pertanian Politeknik Pertanian Negeri Samarinda, Samarinda.

Subandi. (2013). Peran pengelolaan hara kalium untuk produksi pangan di Indonesia. Pengembangan Inovasi Pertanian, 6(1), 1-10.

Sukarman,, Ai Dariah. (2014). Tanah Andosol di Indonesia. Balai Besar Penelitian dan Pengembangan Sumberdaya Lahan Pertanian, Bogor.

Wijaya, K.A. (2008). Nutrisi Tanaman. Prestasi Pustaka, Jakarta. 